УДК 619:614.449.57:591.465.11:619:576.895.1

(C) 2015

Мельничук В. В., асистент

Полтавська державна аграрна академія

\title{
ДЕЗІНВАЗІЙНА ЕФЕКТИВНІСТЬ «БІ-ДЕЗ» ТА «БРОВАДЕЗ-ПЛЮС» ЩОДО ЯЄЦЬ TRICHURIS SUIS
}

\section{Рецензент - доктор ветеринарних наук А. А. Замазій}

\begin{abstract}
Наведені результати вивчення дезінвазійних властивостей вітчизняних дезінфікуючих засобів «Бі-дез» та «Бровадез-плюс» щзодо яєиь трихурисів, виділених з гонад самок гельмінтів. Встановлено, щзо застосовані препарати мали задовільний рівень дезінвазійної ефективності (71,73-89,13\%) стосовно неінвазійних яєиь трихурисів свиней. Разом із тим, найбільи ефективним виявився препарат «Бі-дез» у $2 \%$ концентрациї за експозичіï 60 хв. (ДЕ - 89,13\%). «Бровадезплюс» за тієї ж концентрації та експозииії мав нижчі показники дезінвазійної ефективності щодо яєиь Trichuris suis (ДЕ-79,34\%).
\end{abstract}

Ключові слова: яйчя Trichuris suis, дезінвазійна ефективність, дезінфікуючі засоби.

Постановка проблеми. Важливим фактором передачі гельмінтозної інвазії є об'єкти зовнішнього середовища, контаміновані яйцями паразитів. Це $\epsilon$ причиною швидкої реінвазії тварин і зниження ефективності лікарських препаратів [6, 7]. Тому стратегія профілактики трихурозу свиней повинна базуватися на комплексі заходів, спрямованих на ефективне знешкодження збудників на різних етапах їх розвитку. Найбільш дієвим серед запропонованих науковцями заходів є дезінвазія об'єктів зовнішнього середовища, яка сприяє запобіганню подальшого інвазування тварин. Серед методів, які застосовують для дезінфекції та дезінвазії приміщень і предметів догляду за тваринами найбільш зручними $€$ хімічні $[4,9]$.

Аналіз основних досліджень і публікацій, у яких започатковано розв'язання проблеми. Збудники інвазійних хвороб тварин, які розвиваються до інвазійної стадії у зовнішньому середовищі, на відміну від збудників інфекційних хвороб, більш стійкі до впливу факторів зовнішнього середовища, в тому ж числі до дії хімічних речовин, які використовують для дезінфекції $[3,8]$.

За останні роки за кордоном і на ринку України з'явилися дезінфікуючі засоби на основі ПАР (поверхнево-активні речовини). Дані речовини порушують проникність цитоплазматичної мембрани клітин збудників, інгібують пов'язані з нею ферменти, пригнічують іiі функцію, взаємодіють 3 білково-олігосахаридними та ліпідовмісними біомолекулами мікроорганізму. ПАР застосовують як потенційні добавки у складі композиційних дезінфікуючих препаратів. За здатністю іонізуватися у водних розчинах їх поділяють на аніонні, амфолітні, неіоногенні та катіонні [10].

У подальшому дослідниками був запропонований новий тип дезінфектантів на основі третинних амінів 3 високою антимікробною активністю щодо мікобактерій, грибів і вірусів. За рахунок наявності вільних аміногруп і атома третинного азоту вони формують лужне середовище, яке підсилює їх антимікробну активність, особливо в поєднані з іншими речовинами. Крім цього, ці препарати мають невисоку токсичність [5]. В Україні за останні роки НВФ «Бровафарма» розроблені вітчизняні дезінфікуючі засоби, такі як: «Бровадез-20», «Бровадез-плюс»), «Бі-дез» [1].

За даними Богача М. В. (2007) [2] доведено високий рівень дезінвазійної ефективності «Бровадез20» щодо тест-культури яєць Hetera-kis gallinarum. У зв'язку з цим надзвичайно актуальним є необхідність пошуку сучасних, екологічно безпечних дезінфікуючих засобів, які у певних режимах застосування $\epsilon$ ефективними щодо екзогенних форм розвитку збудника трихурозу свиней.

Метою досліджень було вивчення дезінвазійних властивостей дезінфікуючих засобів вітчизняного виробництва щодо яєць трихурисів.

У завдання досліджень входило: визначити дезінвазійну ефективність (ДЕ) дезінфікуючих засобів «Бі-дез» та «Бровадез-плюс» стосовно яєць, виділених з кінцевих відділів гонад самок гельмінтів у лабораторних умовах.

Матеріали і методи досліджень. Дослідження проводилися упродовж весняно-літнього періоду 2015 року на базі наукової лабораторії кафедри паразитології та ветеринарно-санітарної експертизи факультету ветеринарної медицини Полтавської державної аграрної академії.

Яйця Trichuris suis отримували безпосередньо 3 кінцевих відділів матки кількох самок гельмінтів. Отриману суміш яєць змивали дистильованою водою в окремі чашки Петрі. На кожен дезінфектант для кожної культури яєць гельмінтів було підготовлено по 9 чашок препаратів із різ- 


\section{ВЕТЕРИНАРНА МЕДИЦИНА}

ною концентрацією («Бровадез-плюс» та «Бідез» - $1 \%, 1,5 \%$ та $2 \%$ відповідно) та з різною експозицією (10, 30, 60 хвилин). До попередньо підготовленої суміші яєць Trichuris suis додавали такий самий об'єм розчину препарату певної концентрації. Після відповідної експозиції суміш яєць чотириразово відмивали в дистильованій воді. Чашки Петрі із сумішшю яєць гельмінтів поміщали в термостат за температури $27^{\circ} \mathrm{C}$ i упродовж 45-ти діб вели спостереження. Через кожні п'ять діб культури розглядали під мікроскопом (х 80, х 100). Відзначали ступінь розвитку яєць, враховуючи зміни оболонки, деформацію зародків та стан розвитку личинок або їх пошкодження. Було підготовлено одну контрольну та 18 дослідних чашок Петрі. Оцінку дезінвазійної ефективності проводили за показниками: високий рівень ефективності - 90-100\%, задовільний - 60$90 \%$, незадовільний - до $60 \%$.

Результати дослідження. Результати отриманих даних наведені у таблиці. Встановлено, що дезінфікуючі засоби «Бі-дез» та «Бровадез-плюс» мали показники дезінвазійної ефективності щодо неінвазійних яєць трихурисів свиней на рівні 76,08-89,13 та 71,73-82,60 \% відповідно. Це вказує на задовільний рівень їх ефективності.

Найбільшу загибель та затримку розвитку яєць
Trichuris suis у дослідних культурах реєстрували у процесі застосування $2 \%$ концентрацій дезінфікуючих засобів за експозиції 60 хвилин. Так, після обробки яєць трихурисів $1 \%$ розчином «Бі-дез» за експозиціï 10 хв. 48 \% 3 них гинуло, 30 \% - припиняли розвиток і залишалися на стадії бластомерів; за експозиції 30 хв. - 52 та $27 \%$; 60 хв. - 56 та $25 \%$ відповідно. У процесі використання 1,5\% концентрації «Бі-дезу» кількість загиблих яєць зростала і становила: за експозиції 10 хв. - 55 \%, 30 хв. $-58 \%$, 60 хв. - 65 \%. Після обробки дослідної культури яєць $2 \%$ розчином «Бі-дез» відсоток нерозвинених і загиблих яєць сягав максимуму: за експозиції 10 хв. -64 \%, 30 хв. - 69\%, 60 хв. - $76 \%$.

Препарат «Бровадез-плюс» мав нижчі показники рівня дезінвазійної ефективності стосовно яєць Trichuris suis.

Так, у процесі застосування $1 \%$ розчину засобу відсоток загиблих яєць дорівнював: за експозиції 10 хв. $-40 \%, 30$ хв. $-47 \%, 60$ хв. $-54 \%$. Обробка яєць $1,5 \%$ розчином «Бровадез-плюс» призводила до їх загибелі: за експозиції 10 хв. - 47\%, 30 хв. $53 \%, 60$ хв. $-57 \%$, а $2 \%$ розчином: $52 \%, 56,63 \%$ відповідно. У контрольній культурі на 45-ту добу реєстрували розвиток усередині $92 \%$ яєць рухливих личинок. Лише 5 \% яєць трихурисів гинули, а $3 \%$ - припиняли свій розвиток.

\section{Результати мікроскопї̈ дослідних та контрольної культур маточних яєць Trichuris suis на 45-ту добу експерименту (n=100), \%}

\begin{tabular}{|c|c|c|c|c|c|c|c|c|}
\hline \multirow{3}{*}{\multicolumn{2}{|c|}{ cппо }} & \multicolumn{6}{|c|}{ Концентрація препарату } & \multirow{3}{*}{$\begin{array}{l}\text { A } \\
\text { : } \\
: \\
\text { : } \\
0\end{array}$} \\
\hline & & \multicolumn{2}{|c|}{$1 \%$} & \multicolumn{2}{|c|}{$1,5 \%$} & \multicolumn{2}{|c|}{$2 \%$} & \\
\hline & & 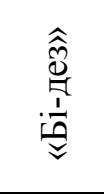 & 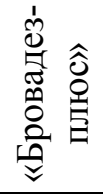 & 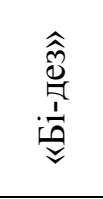 & 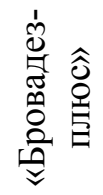 & 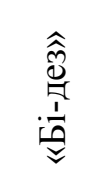 & 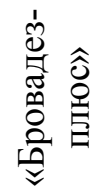 & \\
\hline \multirow{3}{*}{10} & Бластомери & 30 & 34 & 26 & 29 & 21 & 27 & 3 \\
\hline & Личинка & 22 & 26 & 19 & 24 & 15 & 21 & 92 \\
\hline & Загибель & 48 & 40 & 55 & 47 & 64 & 52 & 5 \\
\hline \multicolumn{2}{|r|}{ ДЕ, \% } & 76,08 & 71,73 & 79,34 & 73,91 & 83,69 & 77,17 & - \\
\hline \multirow{3}{*}{30} & Бластомери & 27 & 29 & 24 & 25 & 19 & 25 & 3 \\
\hline & Личинка & 21 & 24 & 18 & 22 & 12 & 19 & 92 \\
\hline & Загибель & 52 & 47 & 58 & 53 & 69 & 56 & 5 \\
\hline \multicolumn{2}{|r|}{ ДЕ, \% } & 77,17 & 73,91 & 80,43 & 76,08 & 86,95 & 79,34 & - \\
\hline \multirow{3}{*}{60} & Бластомери & 25 & 25 & 19 & 23 & 14 & 21 & 3 \\
\hline & Личинка & 19 & 21 & 16 & 20 & 10 & 16 & 92 \\
\hline & Загибель & 56 & 54 & 65 & 57 & 76 & 63 & 5 \\
\hline \multicolumn{2}{|r|}{ ДЕ, \% } & 79,34 & 77,17 & 82,60 & 78,26 & 89,13 & 82,60 & - \\
\hline
\end{tabular}

\section{Висновки:}

1. Дезінфікуючі засоби «Бі-дез» та «Бровадезплюс» мають задовільний рівень (71,73-89,13\%) дезінвазійної ефективності щодо яєць Trichuris suis.
2. Найбільш ефективним проти яєць трихурисів свиней виявився препарат «Бі-дез» у $2 \%$ концентрації за експозиції 60 хвилин (ДЕ $89,13 \%)$. 


\section{БІБЛІОГРАФІЯ}

1. Бензалкония хлорид: инструкция, применение и формула [Электронный ресурс] / Регистр лекарственных средств России : энциклопедия лекарств и товаров аптечного ассортимента, 2006. - Режим доступа : http://www.rlsnet.ru/mnn_ index_id_1809.htm.

2. Богач M. В. Випробування дезінфектантів при гетеракозній інвазії індиків / М.В.Богач // Аграрний вісник Причорномор'я : зб. наук. праць. - Одеса, 2007. - №39. - С. 85-88.

3. «Бровадез-20» як дезінвазійний засіб / [Черепанов А. А., Кумбов П. К., Григорьев А. Г. и др.] // Ветеринарна медицина України. - 2002. №6. - C. 27-28.

4. Ветеринарна дезінфекція: проблеми і перспективи / [Коцюмбас I. Я., Сергієнко О. І., Ковальчук Л. М. та ін.] // Ветеринарна медицина України. - 2009. - №3. - С. 39-41.

5. Современный поход к выбору дезинфицирующих средств в системе профилактики внутрибольничных инфекций (ВБИ) / [Веткина И. Ф., Комаринская Л. В., Ильина И. Ю., Соловьева М. В.] // М. : ФАРМиндекс-Практик. - 2005. - Вып. 7. C. 13-20.
6. Луценко Л. И. Внешняя среда - фактор передачи гельмитоантропозоонозов / Л. И. Луценко : тезисы докл. V междунар. конф. паразитоценологов Украины, 1997 [«Проблемы и перспективы паразитоценологии»]. - Харьков-Луганск, 1997. C. $102-103$.

7. Олехнович Н. И. Трихоцефалез свиней / Н. И. Олехнович, А. И. Ятусевич // Ученые записки Витебской государственной академии ветеринарной медицины. - Витебск, 1994. - Т. 31. C. $127-130$.

8. Черепанова A. A. Методические рекомендации по испытанию и применению средств дезинвазии в ветеринарии / А. А. Черепанов. - М., 1999. - 17 c.

9. Ященко М. Ф. Корозійна дія нових дезінфікуючих засобів 3 пролонгованою дією / М. Ф. Ященко, В. Л. Коваленко // Ветеринарна медицина : міжвід. тем. наук. зб. - Х., 2005. №85. - C. 1200-1203.

10. Merianos $J . J$. Quaternary ammonium antimicrobial compounds / J. J. Merianos // Disinfection, sterilisation and preservation. - Philadelphia : Lea and Febiger, 1991. - P. 225-255. 